\title{
Apresentação Dossiê Imigrações
}

\author{
Érica Sarmiento* \\ Universidade do Estado do Rio de Janeiro \\ Rio de Janeiro - Rio de Janeiro - Brasil
}

Ismênia de Lima Martins ${ }^{* *}$

Universidade Federal Fluminense

Niterói - Rio de Janeiro - Brasil

\author{
Gladys Sabina Ribeiro ${ }^{* * *}$ \\ Universidade Federal Fluminense \\ Niterói - Rio de Janeiro - Brasil
}

* Professora Adjunta na Universidade do Estado do Rio de Janeiro (UERJ); Professora titular do Programa de Mestrado em História da Universidade Salgado de Oliveira. Coordenadora do Laboratório de Estudos de Imigração (Labimi/UERJ) e do Laboratório de Imigração e Estudos Ibéricos (UNIVERSO). É pesquisadora Jovem Cientista Nosso Estado da FAPERJ. E-mail: erisarmiento@gmail.com.

** Professora Emérita da Universidade Federal Fluminense. Coordenadora de Editoração e Acervo da FAPERJ e Membro do CONARQ. Integra a Comissão de Altos Estudos do Programa Memórias Reveladas, da Casa Civil da Presidência da República. Coordena o projeto Portugueses no Brasil, em cooperação com o CEPESE, da Universidade do Porto; o GT Imigração, Identidade e Cidadania, da ANPUH, e o Projeto Entrada de Imigrantes no Brasil, Listagem de Vapores, Arquivo Nacional, BNDES. É presidente da Associação Cultural do Arquivo Nacional e Sócia Honorária do Instituto Histórico Geográfico Brasileiro - IHGB. E-mail: ismeniamartins@uol.com.br.

***Gladys Sabina Ribeiro é professora titular do Instituto de História da Universidade Federal Fluminense; bolsista de produtividade do CNPq e Cientista do Nosso Estado/ FAPERJ. É coordenadora do NEMIC (Núcleo de Estudos de Migrações, Identidades e Cidadania), vice-coordenadora do CEO (Centro de Estudos do Oitocentos) e uma das fundadoras da SEO (Sociedade Brasileira de Estudos do Oitocentos). E-mail: gladyssabina@gmail.com. 
Fenômeno de longa duração, as migrações destacam-se como marca da modernidade. Rearranjos dos grandes impérios, transformações do capital, conflitos civis e novas demandas da organização do trabalho no interior do sistema capitalista provocaram fome e miséria. Tal quadro justifica o vertiginoso deslocamento ocorrido entre 18151914, quando cerca de 50 milhões de mulheres e homens, na maior parte europeus, abandonaram suas terras de origem e dirigiram-se às Américas para iniciar uma nova vida.

Cerca de um século depois, a globalização da economia vem fomentando uma nova onda migratória. Vemos a formação de um extraordinário fenômeno de mobilidade de indivíduos pelo planeta, em uma proporção muito superior àquele período, anteriormente citado, conhecido como da Grande Imigração. De acordo com os dados da Organização das Nações Unidas, em 2013, estimava-se em cerca de 232 milhões o número de imigrantes no mundo.

De um lado, a transnacionalização e a multinacionalização das empresas vem promovendo uma intensa circulação de trabalhadores nos mercados de produção, gerando novas formas de imigração, que devem ser consideradas como componentes da estruturação da sociedade na era da globalização. ${ }^{1}$ De outro, um número recorde de conflitos civis, étnicos e/ou religiosos, e os terríveis desastres ambientais que tem assolado diferentes regiões do planeta se somam à sociedade globalizada para explicar esse maciço deslocamento humano que caracteriza o tempo presente.

Trata-se de uma imigração diferenciada, porque volátil, uma vez que a nova ordem mundial facilita a continuidade desses deslocamentos, dificultando o enraizamento, adicionando-lhe novas e delicadas questões, como a receptividade da sociedade brasileira a esses novos

Canales, Alejandro apud BAENINGER, Rosana. Desafios teórico-metodológicos para a interpretação da migração internacional na sociedade contemporânea. Rev. bras. estud. popul., São Paulo, v. 34, n. 1, p. 181-184, Apr. 2017 . Available from <http://www.scielo.br/scielo.php?script=sci_arttext\&pid=S0102-30982017000100181\&lng=en\&nrm=iso $>$. access on 19 Sept. 2017. http://dx.doi.org/10.20947/s0102-3098a0015. 
grupos e o conflito gerado pela disputa no mercado de trabalho e por direitos políticos, civis e sociais. Além disso, antigas questões se reapresentam ante a opinião pública, como o debate sobre o imigrante desejável, produzindo uma incômoda sensação de retorno ao final do século XIX. Xenofobias reaparecem e nos fazem refletir se o Brasil é de fato um país cordial.

Assim, não seria errado afirmar que a e/imigração é um tema fundamental da história, e que talvez seja, na atualidade, um dos campos mais instigantes para os historiadores. Vale dizer que para o estudo desse fenômeno e dos seus desdobramentos convergem questões centrais do tempo presente como o debate sobre as identidades, os desejos e deveres de memória e as comunidades de sentido, problemas diretamente relacionados ao avanço da globalização sobre os estados e economias nacionais e locais.

É sob a luz das questões e inquietações do presente que o dossiê Imigrações, organizado pelas professoras Ismênia de Lima Martins, Gladys Sabina Ribeiro e Érica Sarmiento, aborda o "longo século XIX"- e os seus diferentes fluxos migratórios e grupos de imigrantes que encontraram nas Américas seu pouso e destino.

Na historiografia relacionada aos estudos migratórios, o Oitocentos estende-se até o ano de 1930, compreendendo, assim, também o denominado período da Grande Imigração (1880-1930) e todo o arcabouço deixado pelo numeroso contingente migratório que cruzou o atlântico. O dossiê reúne um conjunto de textos, escritos por especialistas de longa trajetória na temática, que analisam, desde diferentes perspectivas, as políticas migratórias, as experiências, a memória, a opinião pública e a integração nas sociedades de recepção dos diferentes grupos de imigrantes.

$\mathrm{O}$ continente americano constituiu-se em um grande receptor de imigração ao longo do século XIX. Muito dos jovens Estados, ainda em formação, fortaleceram e consolidaram as suas políticas em função da chegada deimigrantes, queforamentendidoscomoelementos deprogresso e de civilização para as promissoras sociedades em desenvolvimento. 
No caso do Cone Sul, em particular Brasil e Argentina, a imigração representou uma das molas propulsoras das políticas estatais, partícipes das políticas de povoamento, substituição de mão de obra escrava e de branqueamento da população. Já nos primórdios do século XIX, os intelectuais argentinos que fizeram parte da mítica Geração de 37, de Buenos Aires, deixaram em seus escritos a importância do elemento estrangeiro no desenvolvimento de sua sociedade, como foi o caso de Juan Bautista Alberdi, que imortalizou a frase "governar es poblar". No artigo de Alejandro Férnandez, intitulado "La ley argentina de inmigración de 1876 y su contexto histórico", o autor analisa a chamada Ley de Inmigración y Colonización, promulgada no ano de 1876, considerada como um dos pilares legislativos da modernização da Argentina. A lei atribui ao imigrante o seu papel modernizador, tanto no plano da economia como na sociedade como um todo.

Diferente das jovens repúblicas da antiga América espanhola e dos Estados Unidos, o Império brasileiro discutiu e estimulou a questão imigratória no âmbito de uma sociedade ainda escravista. Nesse sentido, o artigo de Paulo Gonçalves realiza uma importante análise sobre as tensões estabelecidas no âmbito do fornecimento e controle da mão de obra para a economia agroexportadora oitocentista. No contexto do período conhecido como de transição do trabalho escravo para o livre, em fins do XIX, a mão de obra assalariada imigrante viu-se refém da mentalidade escravista dos fazendeiros brasileiros, do mandonismo local, e de seus instrumentos de coerção econômica e do uso da força.

O texto de Ana Scott apresenta o estudo da experiência migratória ocorrida entre Portugal (Província da Beira / Concelho da Lousã) e a província de São Paulo (região de Espírito Santo do Pinhal). Nesse caso, a história demográfica forneceu informações importantes para a análise e cruzamento de fontes por meio da exploração de registros paroquiais de batismo e de casamento correspondentes às décadas de 1860 e 1880, da Vila da Lousã (próximo à cidade de Coimbra), e do Núcleo Nova Lousã, no interior da província de São Paulo. Vale ressaltar a relevância dos registros paroquiais como importantes fontes nominativas na construção de tipologias de grupos migratórios. Outrossim, o estudo das variações regionais ou provinciais demonstra um 
amadurecimento dos estudos migratórios, nas últimas décadas, com uma profunda compreensão e conhecimento da realidade de origem e recepção dos migrantes, bem como das relações que se estabelecem entre ambos os universos. A questão da variação da escala aos níveis locais - antes muito limitada- a recortes maiores sem dúvida representou um grande avanço para a análise de fatores microssociais dos processos migratórios.

O patrimônio e o legado cultural construídos por imigrantes na sociedade de acolhimento é uma das contribuições mais significativas relacionadas ao fenômeno migratório. Eloisa Capovilla Ramos, em seu artigo, analisa dois monumentos, um na cidade de Buenos Aires e outro em Caxias dos Sul, erigidos como símbolos da identidade da imigração italiana. Os monumentos, segundo a autora, representam espaços de memória e rememoração que pertencem ao patrimônio cultural de seus países. Na memória dos imigrantes, a história se inicia somente no ponto onde acaba a tradição, momento que, segundo Maurice Halbwachs, se apaga ou se decompõe a memoria social. Quando a memória se dispersa, então o único meio de salvar as lembranças é fixá-las por escrito em uma narrativa, em símbolos, uma vez que as palavras e os pensamentos morrem, mas os escritos permanecem. ${ }^{2}$ A autora em questão dá uma original contribuição para estender tais pressupostos aos monumentos urbanos construídos para celebrar a imigração no quadro urbano.

$\mathrm{O}$ artigo de Martín Pérez Acevedo lança luz sobre a presença imigrante de irlandeses no México. Tal grupo não tinha merecido ainda um esforço de pesquisa sistematizada, talvez por ser quantitativamente inferior no quadro da grande imigração para aquele país. Assim, o autor demonstra, a partir de dados extraídos do Registro de estrangeiros no México do ano de 1925, como esta coletividade formou parte de projetos colonizadores de povoamento do norte do país, ao logo do sé-

2 HALBWACHS, Maurice. A memória coletiva. São Paulo: Centauro Editora, 2006. 
culo XIX, por meio da mineração e do comércio, sendo, muitos deles, agentes de empresas britânicas.

Outra temática que preenche lacunas na historiografia das migrações encontra-se no texto de Oscar Alvarez Gila. Trata-se da análise da opinião pública na imprensa sueca em relação aos primórdios da emigração para os Estados Unidos, um dos destinos preferenciais deste grupo no período da Guerra Civil. O autor realiza um importante levantamento da imprensa da época, ao elencar várias questões afins ao processo migratório publicado na imprensa, como as cartas, as agências de imigração e a posição dos periódicos quanto à emigração.

O conjunto de artigos apresentados nesse dossiê representa uma importante contribuição, do ponto de vista teórico e metodológico, para a nova historiografia das migrações. O leitor poderá acompanhar as discussões realizadas pelos autores e os seus percursos bibliográficos a partir dos quais estabeleceram suas conclusões.

Tais análises contribuem, também, como chaves de leitura para que os historiadores do tempo presente enfrentem os dilemas, as inquietações e as tensões das migrações contemporâneas.

Finalmente, cabe agradecer ao PPGH-UFF por ter custeado a diagramação e a marcação XML deste número. A Almanack é um revista interinstitucional que precisa contar com o apoio dos programas de pós-graduação partícipes da grande aventura que é a manutenção de uma publicação em tempos de escassos recursos. 